\title{
Up and Down: Trends in Students' Perceptions about Learning in a 1:1 Laptop Model - A Longitudinal Study
}

\author{
Tal Berger-Tikochinski, Michal Zion, and Ornit Spektor-Levy \\ School of Education, Bar-Ilan University, Ramat Gan, Israel
}

\author{
tal.bergertiko@gmail.com; michal.zion@biu.ac.il; \\ ornit.spektor-levy@biu.ac.il
}

\begin{abstract}
This is a five-year study conducted with junior high school students studying in a 1:1-laptop program in order to test the effects of the program on various measures related to the students: their attitudes, motivation, perceived school norms, self-efficacy, and behavioral intention towards learning with laptops, according to the Theory of Planned Behavior (TPB).

These variables were tested at two dimensions: 'duration of learning' - the effect of learning in the program on the same students; 'duration of program in school' - the effect of the program on different students in different school years. Participants $(\mathrm{N}=770)$ answered a questionnaire structured according to motivational and TPB variables.

Findings show that attitudes changed over time, but differently for each dimension. For the 'duration of learning', attitudes declined between $7^{\text {th }}$ to $9^{\text {th }}$ grade. Structural equation modeling analysis showed that students' attitudes and self-efficacy explain part of their intention to learn with laptops, therefore ways of maintaining positive attitudes, self-efficacy, and strengthening school norms should be considered. However, for the 'duration of program in school', students' attitudes increased over the years: The attitudes of students who started the program at a later stage were more positive than those who began earlier.
\end{abstract}

This may indicate that students who experience the program at an advanced stage are better prepared, with more realistic expectations. Findings can assist teacher trainers and policymakers with the implementation of similar programs.

Keywords: one-to-one classrooms, personal laptops, motivation, self-efficacy, Theory of Planned

(CC BY-NC 4.0) This article is licensed to you under a Creative Commons Attribution-

NonCommercial 4.0 International License. When you copy and redistribute this paper in full or in part, you need to provide proper attribution to it to ensure that others can later locate this work (and to ensure that others do not accuse you of plagiarism). You may (and we encourage you to) adapt, remix, transform, and build upon the material for any non-commercial purposes. This license does not permit you to use this material for commercial purposes.
Behavior

\section{Introduction}

Technology-rich learning environments are implemented in many countries, with increased investment in technology aimed at reducing the student to computer ratio (Zheng, Arada, Niiya, \& Warschauer, 2014). The number of such programs has increased over the past decade, mostly due to the availability of the technology, its affordability, the

Editor: Janice Whatley

An earlier, shorter version of this paper was presented at the Chais conference 2016, in Raanana, Israel, and included in Y. Eshet-Alkalai, I. Blau, A. Caspi, N. Geri, Y. Kalman, \& V. Silber-Varod (Eds.), Proceedings of the 11th Chais Conference for the Study of Innovation and Learning Technologies 2016: Learning in the Technological Era. Raanana: The Open University of Israel. 
increased digital literacy of teachers and students, and rising awareness of the uses of technology integration among educational policy makers (Balanskat, Bannister, Hertz, Sigillò, \& Vuorikari, 2013; Islam \& Grönlund, 2016; Zheng, Warschauer, Lin, \& Chang, 2016).

There are several models available for implementing Information and Communication technology (ICT) in education. The most extensively used model is a classroom equipped with laptop computers in a one-to-one student to computer ratio (also known as 1:1), especially when the students are allowed to take their computer home. This is a ubiquitous learning environment, where each student has access to a digital device when and where they need it; the technology is accessible 24/7 (Hooft, Swan, Cook, \& Lin, 2007). This model enables two of the unique features of ICT: the ability for individualized learning and the availability of learning that is not constrained by time or by space (Resnik, 2002). 1:1 environments do not require special preparation prior to using the computer, such as going to the computer lab or bringing a computer cart to class. In these classes, the computer becomes part of the students' daily learning routine, at school and at home. The goals of 1:1 programs include innovative pedagogical change, implementation of 21 st century skills among teachers and students, effective use of ICT for learning purposes, improved access to ICT in order to narrow the digital divide, enhanced communication and learning skills, and motivation to learn (Balanskat et al., 2013; Lowther, Inan, Ross, \& Strahl, 2012).

1:1 programs are still scarce in Israel. Even though thousands of teachers and students were equipped with laptops over the past decade (Blau \& Peled, 2012), the average student to computer ratio in 2011 was 1:12. Almost half of the schools that were studied had a higher ratio of 1:20 (State Comptroller, 2011). The majority of 1:1 programs in Israel rely on the initiative of school principals or local education departments for support. They usually include only one or two classes in school, or use the 1:1 program only in specific subjects, a model known as "Islands of Innovation" (Nahmias, Mioduser, \& Forkosh Baruch, 2009). One reason for this scarcity is that the operation of 1:1 programs carries high costs, which include acquisition of computer devices, establishing the necessary technology infrastructure, and teacher training (Penual, 2006). Due to these high costs and the effort required from all parties, it is necessary to have in depth understanding of the educational value of 1:1 programs and the contribution they make to students.

\section{Students' Attitudes, Self-Efficacy, and Motivation in 1:1 Classes}

Students report positive attitudes towards learning with a personal laptop computer (Lowther, et al., 2012) and many prefer to learn with a laptop (Zheng et al., 2016). Research on 1:1 laptop classrooms found several positive effects with students. 1:1 computers have been linked to an increase in students' self-efficacy and personal empowerment (Mouza, 2008; Spektor- Levy, Menashe, Berger-Tikochinski, \& Doron, 2011). Students also reported student-centered learning (Balanskat et al., 2013) and displayed better information skills than students learning without laptops (Spektor-Levy \& Granot-Gilat, 2012). An increase in student computer use (Lowther et al., 2012) and writing (Zheng et al., 2014) was also found.

Overall, students in 1:1 classes report a better learning experience. Islam and Grönlund (2016) and Harper and Milman (2016) reviewed the literature relevant to integration of computers in schools. Both reviews found an increase in students' motivation as a dominant theme in many 1:1 programs. Zheng et al. (2016), who conducted a meta-analysis of research on 1:1 programs, also found that many reported higher motivation and engagement of students. Cavanaugh, Dawson, and Ritzhaupt (2012) found that over $60 \%$ of the teachers in 1:1 classes reported increases in enjoyment, motivation, engagement, on-task behavior, and positive school experience amongst their students. Rosen and Beck-hill (2012) noted that learning in a 1:1 program had a positive effect on elementary students' motivation to learn math and reading. Similar findings regarding an increase in students' motivation to learn in a 1:1 learning environment were reported in many additional programs (e.g., Bebell \& Kay, 2009, Lowther et al., 2005 in Holcomb, 2009). Students who had 
been under achievers displayed higher motivation to learn in an ICT environment, perceiving it as different from traditional learning (Reynolds, Treharne, \& Tripp, 2003).

\section{Information Literacy in 1:1 Classes}

Information literacy is a framework for understanding, searching, evaluating, and using information in such a way that it lays the foundation for lifelong learning. Information literacy includes several skills, such as the ability to find information effectively, critically evaluate information and its sources, and integrate existing and new information (American Library Association, 2000). Despite the importance of these skills, they are often not taught explicitly in the curriculum and most students will acquire them outside of school (Kay, 2010, Perlman, 2010). Research findings suggest that learning in a 1:1 classroom can contribute to students' acquisition of information literacy skills. Spektor-Levy and Granot-Gilat (2012) found that 1:1 laptop students performed significantly better in a computer-based learning task that tested information literacy skills than students from a comparison group who learned without ICT. Zheng et al. (2016) reviewed several examples of 1:1 programs that improved their students' information and technology skills. The meta-analysis they conducted strengthened the finding that writing, editing, and gathering information from the Internet were the most common uses of laptops. Other information literacy skills such as taking notes, searching and organizing information, reading electronic textbooks, finding, analyzing, and sharing information were also prevalent (Crook, Sharma, Wilson, \& Muller, 2013; Warschauer, 2007, 2008).

The results of the International Computer and Information Literacy Study (ICILS) conducted in 2013 showed that students who had greater access to a computer tended to demonstrate better information and computer skills (Fraillon, Ainley, Schulz, Friedman, \& Gebhardt, 2014), and learning in a 1:1 ubiquitous classroom can provide access to the computer when and where the students need it. However, access to a computer does not guarantee the acquisition of information literacy skills. Even students who use the computer frequently will need to learn the appropriate skills with which to evaluate the information they find.

1:1 classes make it possible to search online sources during the lesson, and this was found to be the most common use of the laptops in class (Dunleavy, Dexter, \& Heinecke, 2007). Students reported that in 1:1 learning they can reach online sources and expand their knowledge (Lowther, Ross, \& Morrison, 2003). Searching for information as part of the learning process makes this information relevant and increases the possibility that students will remember it and use it in the future (Grimes \& Warschauer, 2008). While some of the benefits of information skills implementation can be found in other ICT settings, the comprehensive and intensive nature of a 1:1 program enhances these skills in this environment. This may contribute to students' ability, selfefficacy, and motivation to use ICT skills in the future. Léger and Freiman (2016) conducted a qualitative study in which they interviewed former junior high school students ten years after they participated in a 1:1 laptop program. The former students reported that the main skills they acquired in the 1:1 program were technological resourcefulness that assisted them in adapting easily to new technologies without being intimidated, digital self-efficacy, and an open mind towards technology.

\section{Learning in a 1:1 Laptop Program - Can Sustainability be Achieved?}

Studies have shown that 1:1 programs can create a different learning environment, with many advantages. The challenge will be to sustain these changes in order to create ongoing pedagogic processes. However, most of the research on 1:1 programs has been short term (Blackley \& Walker, 2015), focusing on the first or second year of the laptop implementation and not on the following years, when the 1:1 programs became part of the daily teaching and learning routine 
(Lei, 2010). Results from research that continued after the initial implementation suggest that there are significant changes in teachers, students, and schools, some of which were long-term effects that were not predictable in the first years of implementation (Lei, 2010). In some schools the initial enthusiasm of the teachers and students decreased when the computers became part of the daily routine (Grant \& Carolina, 2015; Lowther et al., 2003); a decrease in technology use over time was also reported (Balanskat, et al., 2013). Some schools even canceled 1:1 programs (W. Hu, 2007), due to their high expenses or failure to achieve the anticipated goals (Fleischer, 2012). These findings suggest that when the novelty of the laptops' integration wears off, the advantages found in the first stage of implementation may not necessarily last, but may change over time. Hence the importance of this longitudinal study, which followed a 1:1 laptop program for 5 years.

\section{Technology Acceptance Models - Theory of Planned Behavior}

Students may have diverse previous experiences that can influence their views and attitudes towards using technology (Bennett \& Maton, 2010). Therefore, it is important to recognize what may affect their perceptions of learning in 1:1 programs. Various theoretical models exist to explain the social and psychological motives that affect technology adaption and acceptance. Each model explains different variables concerning technology adaption. One model is The Technology Acceptance Model (TAM), which identifies two major components in technology acceptance: perceived usefulness and perceived ease of use (Davis, 1989). Another model, the Unified Theory of Acceptance and Use of Technology (UTAUT), explains technology acceptance by performance expectancy, effort expectancy, social influence, and facilitating conditions (Venkatesh, Morris, Davis \& Davis, 2003).

The theoretical model chosen for this study is The Theory of Planned Behavior (TPB) (Ajzen, 1985, 1991). TPB was chosen as it is a well-established and robust theoretical model, used as a technology acceptance model in numerous studies, some recently conducted in 1:1 environments (e.g. Courtois et al., 2014; Teo, 2015). According to the TPB model, certain behavior can be explained by behavioral intention, influenced by the attitudes towards the behavior (positive or negative), the subjective norms, which are the social expectations towards this behavior, and the perceived behavioral control, which indicates the amount of control the individuals feel they have over this specific behavior. If one's attitudes towards the behavior are positive, the social norms support it, and one feels one can perform it easily, the behavioral intention will increase, contributing to the performance of the behavior itself. This theory was used to explain technology adaption in educational settings, addressing issues like the perceptions of mobile learning among college students (Cheon, Lee, Crooks, \& Song, 2012) or pre-service teachers' intention to use technology (Valtonen et al., 2015). In this study, we will apply the TPB model to a 1:1 laptop program for junior high school students, as described in Figure 1. Through the TPB model, different measures of technology acceptance can be tested: attitudes, norms, self-efficacy, intention to use 1:1 laptops, and behavior - which is measured in this study as using information skills. 


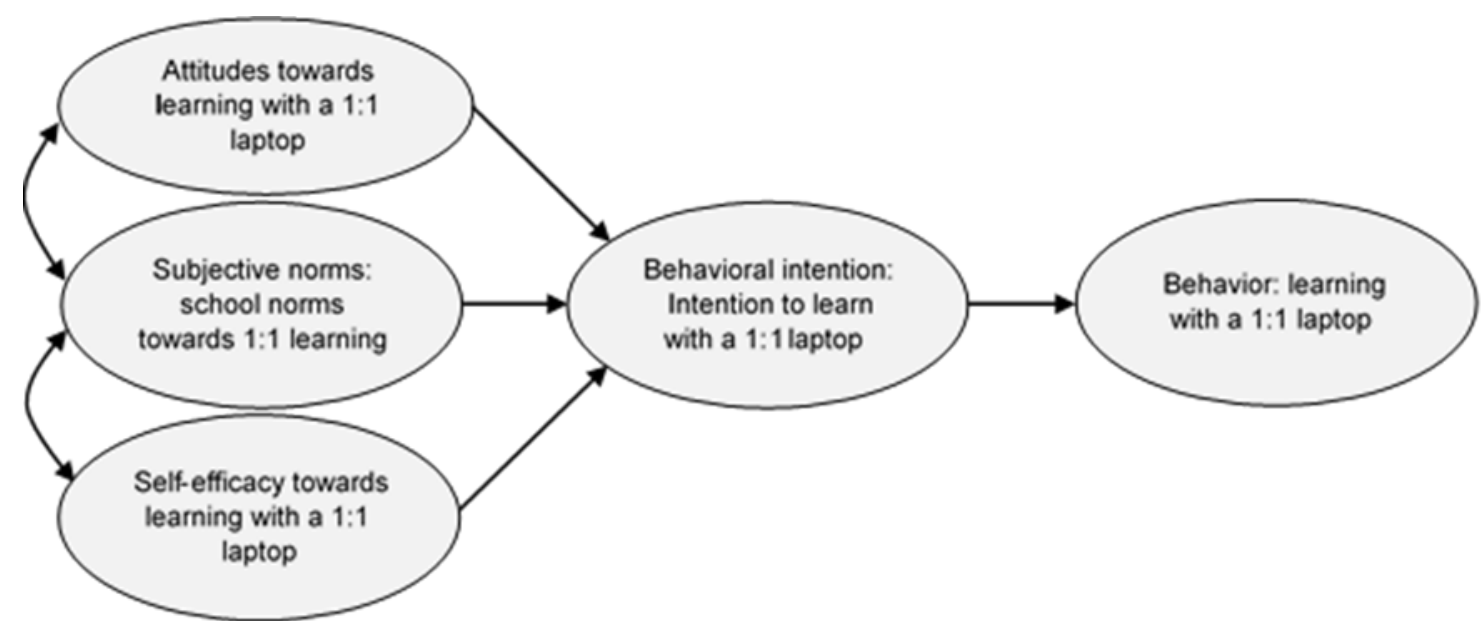

Figure 1: Intention to learn with a 1:1 laptop according to the Theory of Planned Behavior (Ajzen, 1985, 1991)

\section{Research Questions}

This paper focuses on the following questions:

1. What are students' attitudes, perceived school norms, self-efficacy, and intention to learn with a 1:1 laptop, in terms of the Theory of Planned Behavior?

2. Are students' attitudes and perceptions towards learning with a 1:1 laptop stable, or do they change over time? How does this stability or change manifest on (a) the 'duration of learning' - the effect of learning in the program on the same students at two time points; (b) the 'duration of program in school' - the effect of the program on different students of the same age group over different school years.

\section{Method}

\section{Research Setting}

The 1:1 laptop program studied in this research started in 2007 in one small urban town in Israel. The program operates in three schools: two elementary schools in $5^{\text {th }}$ and $6^{\text {th }}$ grade and one junior high school, in $7^{\text {th }}$ through $9^{\text {th }}$ grade. This study began during the third year of the 1:1 laptop program (2009) and lasted as a longitudinal study for 5 years (till 2013). The study examined a wide range of factors among teachers and students. In the paper presented here, we focus on the students and on part of the data that was gathered. The students learnt with a personal laptop for 5 years, from $5^{\text {th }}$ to $9^{\text {th }}$ grade.

The program has several unique aspects: first, the laptop is personal and is part of the daily routine of learning at school and at home. Second, it is operated systematically in all the schools of this urban town in such a way that the students can experience learning with a personal laptop for five consecutive years. In the programs' first years, all the teachers received teacher training and personal support and instruction. Throughout the years, each teacher decided how and when to use the laptop in his or her lessons. The program ends after $9^{\text {th }}$ grade, and the students continue to a high school where no ICT program is implemented. 


\section{Research Sample}

The research included 770 junior high school students in grades 7-9 (13 to 15 years old) who participated in a 1:1 laptop program between the years 2009 and 2013. Of these students, $48.4 \%$ $(\mathrm{N}=369)$ were male and 51.6\% $(\mathrm{N}=393)$ female.

This research followed two student cohorts: 2009-2011 and 2011-2013 (Table 1). Students from both cohorts were from the same junior high school in a small urban town, and from a similar medium- medium-high socio-economic background.

Table 1: Number of students in student cohorts: 2009-2011 and 2011-2013

\begin{tabular}{lll}
\hline & 7 th grade & 9 th grade \\
\hline $2009-2011$ & $42 *$ & 105 \\
$2011-2013$ & 115 & 96 \\
\hline
\end{tabular}

*Since 2009 the cooperation between school and researchers grew and that caused better responds to questionnaires in later years.

Participants were asked to report their daily computer use after school. Differences were found between the two cohorts, for example: $26 \%$ of the $2009-2011$ cohort reported using the computer for 1-2 hours a day, and 21\% used it for 5-6 hours, while $46 \%$ of the 2011-2013 cohort reported using the computer after school for 1-2 hours, and 16\% used it for 5-6 hours.

\section{Research Tools}

The research included a quantitative questionnaire, the Students' Perceived Intentions, Behaviors, and Attitudes - SPIBA, which addressed subjects such as: students' use of the computer at school and at home (e.g., How many hours a day do you use your home computer?), perceived information literacy skills (e.g., "Before I start searching the web, I ask myself questions to figure out what information I'm looking for."; "Before I begin to look for information I carefully choose the keywords I plan to use.") and motivation to learn in a 1:1 program (e.g., "I find great interest when I use a laptop in school."; "I want to get higher grades than other students in 1:1 laptop lessons."). The SPIBA questionnaire is based on a questionnaire validated in Menashe's (2008) study of a 1:1 program and includes 78 items, among them 8 questions regarding students' computer use habits and one open ended question regarding students' attitudes toward continuing to learn in a 1:1 program. The questionnaire also included 70 Likert-style items (some with four levels of agreement and others with seven). The questionnaire includes three parts: motivation, general attitudes towards learning and perceptions towards a 1:1 laptop program.

The first part of the SPIBA questionnaire, the motivation scale, is based on the Motivated Strategies for Learning Questionnaire (MSLQ) developed by Pintrich, Smith, Garcia, \& McKeachie (1993), adapted to a 1:1 program. The motivation scales from the MSLQ that were adapted and used in the SPIBA questionnaire include:

1. Intrinsic goal orientation: Students' perception of why they are engaged in a certain task. Intrinsic goal orientation refers to the perception of a task as a challenge and a purpose in itself, not a means of achieving other goals.

2. Extrinsic goal orientation: Students' perception of a task as being done for a reward or a grade and not for the learning itself. Students who express high extrinsic orientation can be preoccupied with matters other than learning, such as competition with other classmates. 
3. Task value: Students' evaluation of the importance and interest of the task. Students are more likely to be engaged in a task to which they attribute high task value.

4. Control of learning beliefs: Refers to whether the students believe that their efforts to learn will end with a positive result. If students feel their effort is worthwhile and leads to positive results, they are more likely to make this effort in their learning.

5. Self-efficacy for learning and performance: Students' evaluation of their ability to complete a task successfully.

The second part of the SPIBA questionnaire, perceptions towards a 1:1 laptop program, is based on the Theory of Planned Behavior (Figure 1, Table 3), and adapted to learning in a 1:1 laptop program. In this part, we divided the SPIBA questionnaire items into five factors, according to the theory. The factors include attitudes towards learning with a 1:1 laptop; perceived school norms towards 1:1 learning; students' self-efficacy towards learning with a 1:1 computer; intention to learn with a 1:1 computer; behavior - learning with 1:1 computer. The last factor was tested in the context of this study as students' self-report about implementation of information literacy skills.

The third part of the SPIBA questionnaire includes students' attitudes regarding learning in general and not specifically in a 1:1 laptop program. In this part we divided the SPIBA questionnaire items (not included in the previous parts) into three factors (Table 4). The factors include generallearning skills such as reading comprehension or identifying the main ideas in a written text, selfefficacy; students' assessment of their learning, such as assessment of their grades and evaluation of the learning process; students' evaluation of their reflection process or their ability to form their independent opinion.

Two experts and researchers in the field of learning technologies and 1:1 programs validated the factors in each part of the SPIBA questionnaire. When disagreement between experts was found, the experts discussed the issue until full agreement was achieved. In order to measure the internal consistency of the factors, we calculated Cronbach's Alpha for each factor. The reliability measures of the motivational scales, the TPB factors and student attitude factors in the SPIBA questionnaire are presented in Tables 2-4.

The SPIBA questionnaire was administered four times during a five- year period: 2009, 2010, 2011 and 2013. In each administration, students from $7^{\text {th }}, 8^{\text {th }}$ and $9^{\text {th }}$ grades from the same junior high school answered the questionnaire using their laptops. This longitudinal five-year research allowed us to collect data, using the SPIBA questionnaire, from two student cohorts (2009-2011 and 2011-2013). We could follow changes in students' attitudes throughout the years 2009-2013 (on year 2012 data was not collected) and we could follow changes in same students at two points in time: the entry to junior high school in seventh grade and the end, in ninth grade.

Table 2: Factors and reliability of the motivational scales of the SPIBA questionnaire according to MSLQ

\begin{tabular}{ll}
\hline $\begin{array}{l}\text { Motivational Scale according to MSLQ } \\
\text { (Pintrich, Smith, Garcia, \& McKeachie, 1993) }\end{array}$ & $\begin{array}{l}\text { Reliability } \\
\text { Cronbach's Alpha }\end{array}$ \\
\hline Intrinsic goal orientation & $\alpha=0.78$ \\
Extrinsic goal orientation & $\alpha=0.80$ \\
Task value & $\alpha=0.89$ \\
Control of learning beliefs & $\alpha=0.69$ \\
Self- efficacy for learning and performance & $\alpha=0.90$ \\
\hline
\end{tabular}


Table 3: Factors and reliability of the SPIBA questionnaire according to the TPB

\begin{tabular}{ll}
\hline $\begin{array}{l}\text { Factors according to the TPB } \\
\text { (Ajzen, 1985,1991) }\end{array}$ & $\begin{array}{l}\text { Reliability } \\
\text { Cronbach's Alpha }\end{array}$ \\
\hline $\begin{array}{l}\text { Attitudes towards learning with a 1:1 laptop } \\
\begin{array}{l}\text { Subjective norms: school norms towards 1:1 learning } \\
\text { (This factor is composed from one item, therefore reliability was not calculated) }\end{array}\end{array}$ & $\alpha=0.88$ \\
Self-efficacy towards learning with a 1:1 laptop & $\alpha=0.85$ \\
$\begin{array}{l}\text { Behavioral intention: Intention to learn with a 1:1 laptop } \\
\text { Behavior: learning with a 1:1 laptop }\end{array}$ & $\alpha=0.81$ \\
\hline
\end{tabular}

Table 4: Factors and reliability of the SPIBA questionnaire regarding general attitudes towards learning

\begin{tabular}{ll}
\hline General attitudes towards learning & $\begin{array}{l}\text { Reliability } \\
\text { Cronbach's Alpha }\end{array}$ \\
\hline General learning skills & $\alpha=0.70$ \\
Self-efficacy & $\alpha=0.57$ \\
Evaluation of the learning process & $\alpha=0.70$ \\
\hline
\end{tabular}

\section{Results}

This research examined the impact of learning in a 1:1 laptop program on junior high school students' attitudes, motivation, self-efficacy and behavioral intention towards learning with 1:1 personal laptops, as measured by the SPIBA questionnaire based on MSLQ motivation scales, the Theory of Planned Behavior (TPB) scales, and students' general attitudes towards learning. We used these different variables and analyzed them over time, through a longitudinal research design, in order to examine learning in a 1:1 laptop classroom as a complex phenomenon. These variables were tested at two dimensions: 'duration of learning (with a personal laptop)' - the effect of learning in the program on the same students at two points in time; 'duration of program in school' - the effect of the program on different students of the same age group in different school years.

\section{Change at 'Duration of Learning' Dimension (Same Students at Two Time Points) at the Beginning and End of Junior High School}

Findings presented in this section refer to the 'duration of learning' dimension- the effect of learning in the program on the same students at two points in time. For this purpose, we tested two student cohorts (2009-2011 and 2011-2013) at two time points: the beginning of junior high school in seventh grade and the end of junior high in ninth grade. In the data analysis, we used independent sample t-tests, due to the requirement of the Chief Scientist of the Ministry of Education that the student questionnaire be anonymous.

First, we examined the SPIBA motivation scales for these two cohorts (for 2009-2011 see Table 5, for 2011-2013 see Table 6). 
Table 5: SPIBA motivation scales, same students 2009-2011

\begin{tabular}{|c|c|c|c|c|c|}
\hline & $\begin{array}{c}2009 \\
(\mathrm{~N}=42)\end{array}$ & & $\begin{array}{c}2011 \\
(\mathrm{~N}=105)\end{array}$ & & \\
\hline & $M$ & $S D$ & $M$ & $S D$ & t-value \\
\hline Intrinsic goal orientation & 5.02 & 1.16 & 4.06 & 1.53 & $3.69^{* *}$ \\
\hline Extrinsic goal orientation & 5.35 & 1.28 & 4.61 & 1.52 & $2.77 * *$ \\
\hline Task value & 5.27 & 1.15 & 4.28 & 1.57 & $4.21 * *$ \\
\hline Control of learning beliefs & 5.16 & .98 & 4.16 & 1.48 & $4.77 * *$ \\
\hline Self- efficacy for learning and performance & 5.59 & .98 & 4.98 & 1.36 & $3.06^{* *}$ \\
\hline
\end{tabular}

Table 6: SPIBA motivation scales, same students 2011-2013

\begin{tabular}{|c|c|c|c|c|c|}
\hline & $\begin{array}{c}2011 \\
(\mathrm{~N}=115)\end{array}$ & & $\begin{array}{c}2013 \\
(\mathrm{~N}=96)\end{array}$ & & \\
\hline & $M$ & $S D$ & $M$ & $S D$ & t-value \\
\hline Intrinsic goal orientation & 4.76 & 1.27 & 4.44 & 1.38 & 1.73 \\
\hline Extrinsic goal orientation & 5.21 & 1.34 & 4.79 & 1.62 & $2.02 *$ \\
\hline Task value & 5.09 & 1.38 & 4.60 & 1.50 & $2.45^{*}$ \\
\hline Control of learning beliefs & 4.77 & 1.31 & 4.50 & 1.39 & 1.44 \\
\hline Self- efficacy for learning and performance & 5.30 & 1.25 & 4.95 & 1.50 & 1.81 \\
\hline
\end{tabular}

Findings show a significant decrease in students' attitudes that occurred between grades 7 and 9 . In all the SPIBA motivation scales for students from the 2009-2011 cohort, attitudes were higher in $7^{\text {th }}$ grade, the beginning of junior high school, than in $9^{\text {th }}$ grade, its end. For example, students' extrinsic goal orientation declined from mean 5.35 (SD 1.28) to mean 4.61 (1.52) between 2009 and $2011\left(\mathrm{t}_{(144)}=2.77 \mathrm{p}<0.01\right)$ and from mean 5.21 (SD 1.34) to mean 4.79 (SD 1.62) between 2011 and $2013\left(\mathrm{t}_{(205)}=2.02 \mathrm{p}<0.05\right)$. The results in some scales of the 2011-2013 cohort are similar: a significant decline in students' attitudes was found for the motivation scales concerning external orientation and task value; hence, students' attitudes were higher in 7th grade compared to their attitudes in 9th grade.

We then checked the perceptions towards learning with personal laptops of students from the same two cohorts (2009-2011 and 2011-2013), according to the TPB, the theoretical model for this research.

Like the SPIBA motivation scales results for these cohorts, students' perceptions towards a 1:1 laptop program also tend to decline between $7^{\text {th }}$ and $9^{\text {th }}$ grade. For example, students' attitudes towards learning with a 1:1 laptop declined from mean 5.16 (SD 1.27) in 2009 to mean 4.15 (SD $1.66)$ in $2011\left(\mathrm{t}_{(98.84)}=3.96 \mathrm{p}<0.01\right)$ and from mean 5.05 (SD 1.47) in 2011 to mean 4.52 (SD $1.59)$ in $2013\left(\mathrm{t}_{(206)}=2.47 \mathrm{p}<0.05\right)$. In the 2009-2011 cohort (Table 7), this decrease was significant for attitudes towards learning with a 1:1 laptop, school norms, self-efficacy, and the intention to learn with a 1:1 laptop. For the 2011-2013 cohort (Table 8), a significant decline was found in attitudes, behavioral intention, and self-report of behavior, defined in this research as using information literacy skills. 
Table 7: SPIBA-TPB factors, same students 2009-2011

\begin{tabular}{|c|c|c|c|c|c|}
\hline & \multicolumn{2}{|c|}{$\begin{array}{c}2009 \\
(\mathrm{~N}=42)\end{array}$} & \multicolumn{2}{|c|}{$\begin{array}{c}2011 \\
(\mathrm{~N}=105)\end{array}$} & \multirow[b]{2}{*}{$\mathrm{t}$-value } \\
\hline & $M$ & $S D$ & $M$ & $S D$ & \\
\hline Attitudes towards learning with a $1: 1$ laptop $^{1}$ & 5.16 & 1.27 & 4.15 & 1.66 & $3.96^{* *}$ \\
\hline Self-efficacy towards learning with a 1:1 laptop ${ }^{1}$ & 5.52 & 1.07 & 4.92 & 1.44 & $2.46^{* *}$ \\
\hline School norms towards $1: 1$ learning $^{1}$ & 5.24 & 1.76 & 4.24 & 2.06 & $2.95^{* *}$ \\
\hline Behavioral intention: intention to learn with a $1: 1$ laptop $^{1}$ & 5.38 & 1.04 & 4.70 & 1.46 & $3.18^{* *}$ \\
\hline Behavior: learning with a 1:1 laptop ${ }^{2}$ & 2.75 & .63 & 2.56 & .60 & 1.70 \\
\hline
\end{tabular}

Table 8: SPIBA-TPB factors, same students 2011-2013

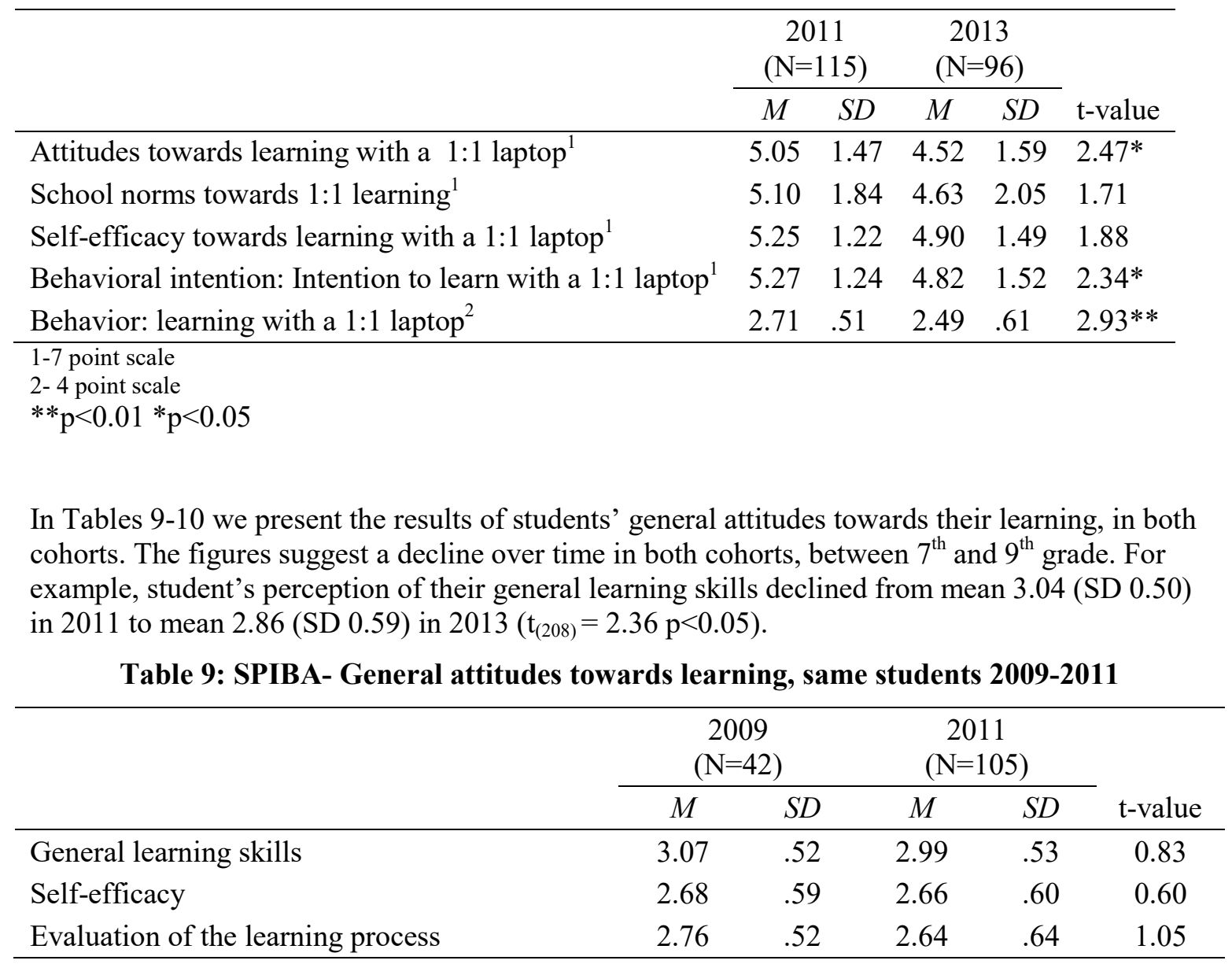


Table 10: SPIBA- General attitudes towards learning, same students 2011-2013

\begin{tabular}{lccccc}
\hline & \multicolumn{2}{c}{$\begin{array}{c}2011 \\
(\mathrm{~N}=115)\end{array}$} & \multicolumn{2}{c}{2013} \\
& $M$ & $S D$ & $M$ & $S D$ & t-value \\
\cline { 2 - 5 } & 3.04 & .50 & 2.86 & .59 & $2.36^{*}$ \\
General learning skills & 2.83 & .57 & 2.67 & .64 & 1.95 \\
Self-efficacy & 2.71 & .58 & 2.69 & .64 & 0.14 \\
Evaluation of the learning process & & & & &
\end{tabular}

$* \mathrm{p}<0.05$

In order to further examine students' perceptions towards a 1:1 laptop program and the relationship between different variables, we conducted a path analysis (Figures 2 and 3) using Structural Equation Modeling analysis (SEM), superimposed onto the TPB model adapted to learning with a 1:1 laptop (Figure 1). This model includes students' attitudes, school norms, self-efficacy, behavioral intention, and self-report of behavior, measured in this research as implementing information literacy skills. The numbers on the connecting lines of the model represent the $\beta$ values.

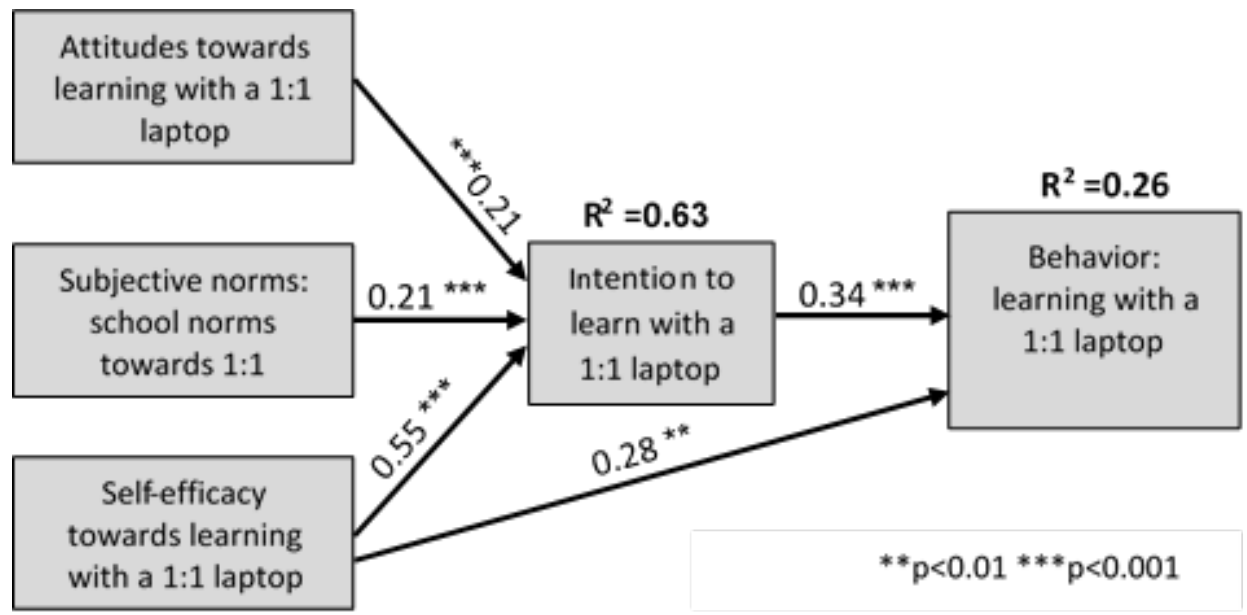

Figure 2: SEM model according to the SPIBA-TPB factors for learning with a 1:1 personal laptop, 2011

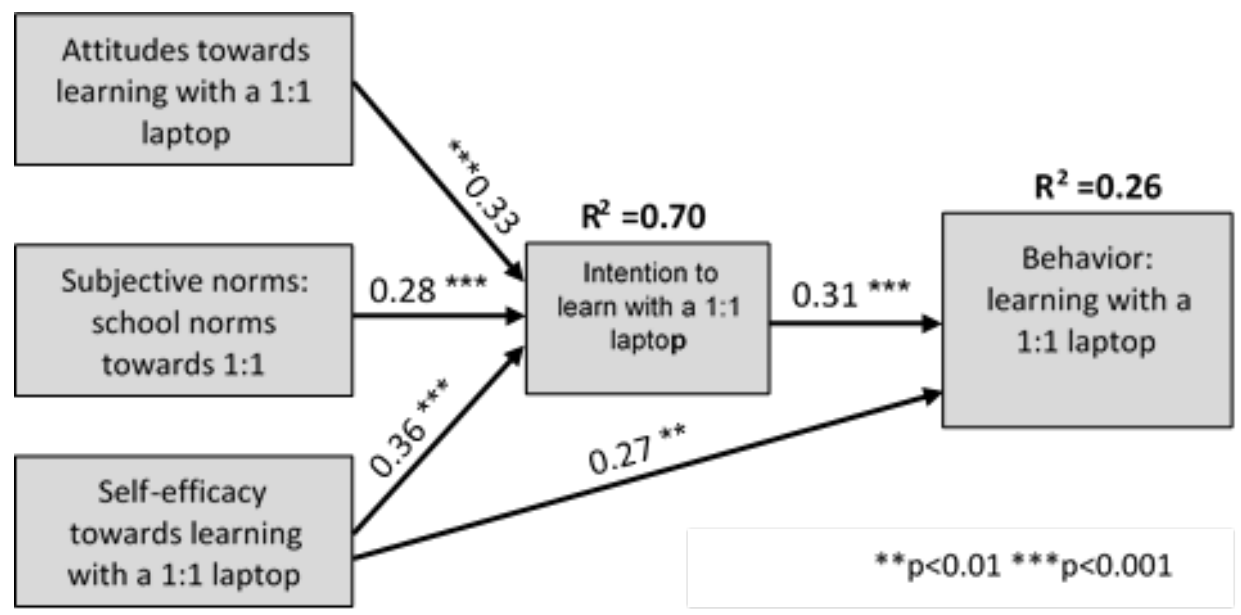

Figure 3: SEM model according to the SPIBA-TPB factors for learning with a 1:1 personal laptop, 2013 
In order to assess the fit of the model to the data, we used several goodness-of-fit indices. The first is the chi-square statistic $\left(\chi^{2}\right)$, which should be statistically non-significant (Kline, 2011). Other indices include the NFI, CFI, and RMSEA, which were compared to the recommended levels (Cheon et al., 2012; L. T. Hu \& Bentler, 1999). The results for both models indicate a good fit. For the 2011 model, the chi-square was found not significant $\left(\chi^{2}=0.246 \mathrm{df}=2 \mathrm{p}=0.884\right)$, $\mathrm{NFI}=1.000$ (recommended $>0.95), \mathrm{CFI}=1.000$ (recommended $>0.95$ ) and RMSEA $=0.000$ (recommended $<0.05$ ). For the 2013 model, the chi-square was found not significant $\left(\chi^{2}=1.008 \mathrm{df}=2\right.$ $\mathrm{p}=0.604), \mathrm{NFI}=0.999($ recommended $>0.95), \mathrm{CFI}=1.000($ recommended $>0.95)$ and RMSEA $=0.000$ (recommended $<0.05$ ).

We found that the biggest impact on students' intention to learn with a 1:1 laptop is their selfefficacy towards learning with a 1:1 laptop $(\beta=0.55 p<0.001$ in 2011 and $\beta=0.36 p<0.001$ in 2013). In the path analysis for 2011 (Figure 2), attitudes towards learning with a 1:1 laptop, school norms and self-efficacy explained $63 \%$ of variance $\left(\mathrm{R}^{2}=0.63\right)$, in the second path analysis, in 2013 (Figure 3) they explained $70 \%$ of variance $\left(R^{2}=0.70\right)$.

In conclusion, the findings presented in this section indicate that at the 'duration of learning' dimension (the effect of learning in the program - same students at two time points) students' attitudes and perceptions towards different measures of learning in a 1:1 program tend to decrease over time, from the beginning of junior high school at $7^{\text {th }}$ grade to its end in $9^{\text {th }}$ grade. This tendency was found in both student cohorts (2009-2011 and 2011-2013), and was reflected in several measures including most of the motivation scales and students' perceptions towards the 1:1 laptop program according to the TPB, and in some of students' general attitudes towards learning. Findings from the SEM analysis show that students' self-efficacy toward learning with a 1:1 laptop computer has the strongest impact on their intention to learn with a 1:1 laptop.

\section{Change at 'Duration of Program in School' Dimension (Different Students of the Same Age Group at Different School Years) Between the Years 2009 and 2013}

In the light of the findings in the previous section, and the decline in students' attitudes over time at the 'duration of learning' dimension, we conducted additional data analysis to examine the attitudes and perceptions of students through another dimension: 'duration of program in school' the effect of the program on different students of the same age group in different school years.

For this purpose, we examined all students in each year, using a One-way ANOVA. We examined the findings of the questionnaire administered in 2009, 2010, 2011 and 2013. As we did in the first section, we examined the SPIBA motivation scales (Table 11), students' perceptions towards a 1:1 laptop program using the TPB (Table 12) and general attitudes toward learning (Table 13).

When comparing the SPIBA motivation scales at 'duration of program in school' dimension (Table 11) it appears that over the years 2009 to 2013 students' attitudes are similar and often more positive in 2013. For example, students' extrinsic goal orientation increased from mean 4.91 (SD 1.64) in 2009 to mean 5.16 (SD 1.49) in $2013\left(\mathrm{~F}_{(3,756)}=2.99 \mathrm{p}<0.05\right)$. This increase was significant for extrinsic goal orientation and control of learning beliefs. Scheffe post hoc tests indicate that the difference is between 2011 and 2013. 
Table 11: SPIBA motivation scales, different students 2009-2013 (No data was collected in 2012)

\begin{tabular}{lccccccccc}
\hline & \multicolumn{2}{c}{2009} & \multicolumn{2}{c}{2010} & \multicolumn{2}{c}{2011} & \multicolumn{2}{c}{2013} \\
& \multicolumn{2}{c}{$(\mathrm{N}=66)$} & $(\mathrm{N}=75)$ & $(\mathrm{N}=336)$ & \multicolumn{2}{c}{$(\mathrm{N}=293)$} & \\
\cline { 2 - 8 } & $M$ & $S D$ & $M$ & $S D$ & $M$ & $S D$ & $M$ & $S D$ & $\mathrm{~F}$ \\
\hline Intrinsic goal orientation & 4.54 & 1.51 & 4.56 & 1.55 & 4.46 & 1.44 & 4.71 & 1.29 & 1.64 \\
Extrinsic goal orientation & 4.91 & 1.64 & 4.83 & 1.70 & 4.80 & 1.51 & 5.16 & 1.49 & $2.99^{*}$ \\
Task value & 4.69 & 1.62 & 5.04 & 1.54 & 4.72 & 1.54 & 4.99 & 1.47 & 2.24 \\
Control of learning beliefs & 4.78 & 1.43 & 4.78 & 1.29 & 4.42 & 1.46 & 4.77 & 1.33 & $4.09 * *$ \\
$\begin{array}{l}\text { Self-efficacy for learning and perfor- } \\
\text { mance }\end{array}$ & 5.07 & 1.50 & 5.13 & 1.51 & 5.03 & 1.38 & 5.18 & 1.36 & 0.62 \\
\hline
\end{tabular}

$* * \mathrm{p}<0.01 * \mathrm{p}<0.05$

Table 12: SPIBA-TPB factors, different students 2009-2013

\begin{tabular}{|c|c|c|c|c|c|c|c|c|c|}
\hline & \multicolumn{2}{|c|}{$\begin{array}{c}2009 \\
(\mathrm{~N}=66)\end{array}$} & \multicolumn{2}{|c|}{$\begin{array}{c}2010 \\
(\mathrm{~N}=75)\end{array}$} & \multicolumn{2}{|c|}{$\begin{array}{c}2011 \\
(\mathrm{~N}=336)\end{array}$} & \multicolumn{2}{|c|}{$\begin{array}{c}2013 \\
(\mathrm{~N}=293)\end{array}$} & \multirow[b]{2}{*}{$\mathrm{F}$} \\
\hline & $M$ & $S D$ & $M$ & $S D$ & $M$ & $S D$ & $M$ & $S D$ & \\
\hline $\begin{array}{l}\text { Attitudes towards learning with a } 1: 1 \text { lap- } \\
\text { top }^{1}\end{array}$ & 4.61 & 1.69 & 4.97 & 1.63 & 4.67 & 1.61 & 4.92 & 1.53 & 1.90 \\
\hline school norms towards $1: 1$ learning $^{1}$ & 4.88 & 2.09 & 4.82 & 2.13 & 4.64 & 2.06 & 5.04 & 1.91 & 2.07 \\
\hline $\begin{array}{l}\text { Self-efficacy towards learning with a } 1: 1 \\
\text { laptop }\end{array}$ & 5.03 & 1.51 & 5.03 & 1.57 & 4.98 & 1.41 & 5.12 & 1.39 & 0.47 \\
\hline $\begin{array}{l}\text { Behavioral intention: Intention to learn with } \\
\text { a } 1: 1 \text { laptop }^{1}\end{array}$ & 4.89 & 1.52 & 4.89 & 1.64 & 4.90 & 1.43 & 5.14 & 1.35 & 1.69 \\
\hline Behavior: learning with a 1:1 laptop ${ }^{2}$ & 2.65 & 0.68 & 2.78 & 0.67 & 2.59 & 0.63 & 2.66 & 0.60 & 1.92 \\
\hline
\end{tabular}

$1-7$ point scale

2- 4 point scale

The results (Table 12) suggest that at 'duration of program in school' dimension students' perceptions towards some measures of 1:1 laptop program tend to increase over time, between 2009 and 2013. This tendency was not significant.

Table 13: SPIBA- General Attitudes towards learning, different students 2009-2013

\begin{tabular}{lccccccccc}
\hline & \multicolumn{2}{c}{2009} & \multicolumn{2}{c}{2010} & \multicolumn{2}{c}{2011} & \multicolumn{2}{c}{2013} \\
& $(\mathrm{~N}=66)$ & \multicolumn{2}{c}{$(\mathrm{N}=75)$} & $(\mathrm{N}=336)$ & $(\mathrm{N}=293)$ & \\
\cline { 2 - 9 } & $M$ & $S D$ & $M$ & $S D$ & $M$ & $S D$ & $M$ & $S D$ & $\mathrm{~F}$ \\
\hline General learning skills & 2.94 & .58 & 3.01 & .62 & 2.93 & .57 & 3.01 & .57 & 1.22 \\
Self-efficacy & 2.63 & .61 & 2.90 & .74 & 2.73 & .59 & 2.83 & .57 & $4.05^{* *}$ \\
Evaluation of the learning process & 2.61 & .63 & 2.82 & .59 & 2.65 & .65 & 2.80 & .59 & $4.40^{* *}$ \\
\hline
\end{tabular}

$* * \mathrm{p}<0.01$

The results (Table 13) indicate that at 'duration of program in school' dimension students' attitudes toward some measures of learning tend to change positively over time, between 2009 and 2013. For example, students' self-efficacy increased from mean 2.63 (SD 0.61) in 2009 to mean 2.83 (SD 0.57) in $2013\left(\mathrm{~F}_{(3,765)}=4.05 \mathrm{p}<0.01\right)$. This change was significant for self-efficacy and evaluation of the learning process. Scheffe post hoc tests indicate that the difference is between 2011 and 2013.

For further examination of these findings, we compared the perceptions of different students at specific grade levels between 2011 and 2013, according to the SPIBA motivation scales, stu- 
dents' perceptions towards a 1:1 laptop program and general attitudes towards learning. In the data analysis, we used an independent samples t-test, since we compared different students.

Table 14: SPIBA motivation scales, different students in $7^{\text {th }}$ grade, 2011, 2013

\begin{tabular}{|c|c|c|c|c|c|}
\hline \multicolumn{6}{|c|}{$7^{\text {th }}$ grade } \\
\hline & \multicolumn{2}{|c|}{$\begin{array}{c}2011 \\
(\mathrm{~N}=115)\end{array}$} & \multicolumn{2}{|c|}{$\begin{array}{c}2013 \\
(\mathrm{~N}=55)\end{array}$} & \multirow[b]{2}{*}{ t-value } \\
\hline & $M$ & $S D$ & $M$ & $S D$ & \\
\hline Intrinsic goal orientation & 4.76 & 1.27 & 5.32 & 1.06 & $-2.85 * *$ \\
\hline Extrinsic goal orientation & 5.21 & 1.34 & 5.59 & 1.25 & -1.79 \\
\hline Task value & 5.09 & 1.38 & 5.43 & 1.36 & -1.49 \\
\hline Control of learning beliefs & 4.77 & 1.31 & 5.13 & 1.37 & -1.64 \\
\hline $\begin{array}{l}\text { Self-efficacy for learning and perfor- } \\
\text { mance }\end{array}$ & 5.30 & 1.25 & 5.56 & 1.13 & -1.33 \\
\hline
\end{tabular}

$* * \mathrm{p}<0.01 * \mathrm{p}<0.05$

Table 15: SPIBA motivation scales, different students in $8^{\text {th }}$ grade, 2011, 2013

\begin{tabular}{|c|c|c|c|c|c|}
\hline & \multicolumn{4}{|c|}{$8^{\text {th }}$ grade } & \multirow[b]{3}{*}{ t-value } \\
\hline & \multicolumn{2}{|c|}{$\begin{array}{c}2011 \\
(\mathrm{~N}=116)\end{array}$} & \multicolumn{2}{|c|}{$\begin{array}{c}2013 \\
(\mathrm{~N}=142)\end{array}$} & \\
\hline & $M$ & $S D$ & $M$ & $S D$ & \\
\hline Intrinsic goal orientation & 4.53 & 1.45 & 4.65 & 1.23 & -0.72 \\
\hline Extrinsic goal orientation & 4.58 & 1.59 & 5.24 & 1.44 & $-3.47 * *$ \\
\hline Task value & 4.74 & 1.57 & 5.08 & 1.44 & -1.79 \\
\hline Control of learning beliefs & 4.30 & 1.54 & 4.82 & 1.23 & $-2.89 * *$ \\
\hline $\begin{array}{l}\text { Self-efficacy for learning and perfor- } \\
\text { mance }\end{array}$ & 4.81 & 1.49 & 5.19 & 1.33 & $-2.11 *$ \\
\hline \multicolumn{6}{|l|}{$* * \mathrm{p}<0.01 * \mathrm{p}<0.05$} \\
\hline \multicolumn{6}{|c|}{ Table 16: SPIBA motivation scales, different students in } \\
\hline 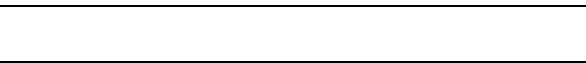 & \multicolumn{4}{|c|}{$9^{\text {th }}$ grade } & \\
\hline & \multicolumn{2}{|c|}{$\begin{array}{c}2011 \\
(\mathrm{~N}=105)\end{array}$} & \multicolumn{2}{|c|}{$\begin{array}{c}2013 \\
(\mathrm{~N}=96)\end{array}$} & \\
\hline & $M$ & $S D$ & $M$ & $S D$ & t-value \\
\hline Intrinsic goal orientation & 4.06 & 1.53 & 4.44 & 1.38 & -1.82 \\
\hline Extrinsic goal orientation & 4.61 & 1.52 & 4.79 & 1.62 & -0.81 \\
\hline Task value & 4.28 & 1.57 & 4.60 & 1.50 & -1.47 \\
\hline Control of learning beliefs & 4.16 & 1.48 & 4.50 & 1.39 & -1.67 \\
\hline $\begin{array}{l}\text { Self-efficacy for learning and perfor- } \\
\text { mance }\end{array}$ & 4.98 & 1.36 & 4.95 & 1.50 & 0.13 \\
\hline
\end{tabular}

Findings (Tables 14-16) suggest that students who started the program at a later stage tended to display more positive attitudes compared to students who participated in the program in its first years. This is evident especially for $8^{\text {th }}$ grade students. For example, $8^{\text {th }}$ grade students' extrinsic 
goal orientation increased from mean 4.58 (SD 1.59) in 2011 to mean 5.24 (SD 1.44) in 2013 $\left(\mathrm{t}_{(253)}=-3.47 \mathrm{p}<0.01\right)$.

Table 17: SPIBA-TPB factors, different students in $7^{\text {th }}$ grade, 2011, 2013

\begin{tabular}{lcccccc}
\hline & \multicolumn{5}{c}{$7^{\text {th }}$ grade } \\
\hline & \multicolumn{2}{c}{2011} & \multicolumn{2}{c}{2013} & \\
& $(\mathrm{~N}=115)$ & \multicolumn{2}{c}{$(\mathrm{N}=55)$} & \\
\cline { 2 - 6 } & $M$ & $S D$ & $M$ & $S D$ & t-value \\
Attitudes towards learning with a 1:1 laptop $^{1}$ & 5.05 & 1.47 & 5.36 & 1.38 & -1.32 \\
Self-efficacy towards learning with a 1:1 laptop $^{1}$ & 5.25 & 1.22 & 5.51 & 1.20 & -1.29 \\
School norms towards 1:1 learning $^{1}$ & 5.10 & 1.84 & 5.41 & 1.66 & -1.01 \\
Behavioral intention: Intention to learn with a 1:1 laptop $^{1}$ & 5.27 & 1.24 & 5.55 & 1.11 & -1.43 \\
Behavior: learning with a 1:1 laptop $^{2}$ & 2.71 & .51 & 2.78 & .59 & -0.72 \\
\hline
\end{tabular}

1-7 point scale

2- 4 point scale

Table 18: SPIBA-TPB factors, different students in $8^{\text {th }}$ grade, 2011, 2013

\begin{tabular}{|c|c|c|c|c|c|}
\hline & \multicolumn{4}{|c|}{$8^{\text {th }}$ grade } & \multirow[b]{3}{*}{ t-value } \\
\hline & \multicolumn{2}{|c|}{$\begin{array}{c}2011 \\
(\mathrm{~N}=116)\end{array}$} & \multicolumn{2}{|c|}{$\begin{array}{c}2013 \\
(\mathrm{~N}=142)\end{array}$} & \\
\hline & $M$ & $S D$ & $M$ & $S D$ & \\
\hline Attitudes towards learning with a $1: 1$ laptop $^{1}$ & 4.76 & 1.62 & 5.02 & 1.48 & -1.36 \\
\hline Self-efficacy towards learning with a 1:1 laptop ${ }^{1}$ & 4.78 & 1.54 & 5.12 & 1.36 & -1.90 \\
\hline School norms towards 1:1 learning ${ }^{1}$ & 4.54 & 2.18 & 5.21 & 1.86 & $-2.52 * *$ \\
\hline Behavioral intention: Intention to learn with a $1: 1$ laptop $^{1}$ & 4.70 & 1.53 & 5.18 & 1.27 & $-2.69 * *$ \\
\hline Behavior: learning with a $1: 1$ laptop $^{2}$ & 2.51 & .74 & 2.73 & .57 & $-2.63 * *$ \\
\hline
\end{tabular}

1-7 point scale

2- 4 point scale

$* * \mathrm{p}<0.01$

Table 19: SPIBA-TPB factors, different students in $9^{\text {th }}$ grade, 2011, 2013

\begin{tabular}{lccccc}
\hline & \multicolumn{5}{c}{$9^{\text {th }}$ grade } \\
\hline & \multicolumn{2}{c}{2011} & \multicolumn{2}{c}{2013} & \\
& $(\mathrm{~N}=105)$ & \multicolumn{2}{c}{$(\mathrm{N}=96)$} & \\
\cline { 2 - 6 } & $M$ & $S D$ & $M$ & $S D$ & t-value \\
Attitudes towards learning with a 1:1 laptop $^{1}$ & 4.15 & 1.66 & 4.52 & 1.59 & -1.61 \\
Self-efficacy towards learning with a 1:1 laptop $^{1}$ & 4.92 & 1.44 & 4.90 & 1.49 & 0.09 \\
School norms towards 1:1 learning $^{1}$ & 4.24 & 2.06 & 4.63 & 2.05 & -1.35 \\
Behavioral intention: Intention to learn with a 1:1 laptop $^{1}$ & 4.70 & 1.46 & 4.82 & 1.52 & -0.58 \\
Behavior: learning with a 1:1 laptop $^{2}$ & 2.56 & .60 & 2.49 & .61 & 0.85 \\
\hline
\end{tabular}

1-7 point scale

2- 4 point scale

Like the findings of the SPIBA motivation scales, these showed that students who started the program at a later stage tended to display more positive attitudes compared to students who participated in the program in its first years (Tables 17-19). Again, this change was evident especially in $8^{\text {th }}$ grade students. For example, $8^{\text {th }}$ grade students' behavioral intention to learn with a 1:1 laptop 
increased from mean 4.70 (SD 1.53) in 2011 to mean 5.18 (SD 1.27) in $2013\left(\mathrm{t}_{(222.96)}=-2.69\right.$ $\mathrm{p}<0.01)$.

Tables 20-22 present the results of students' general attitudes towards their learning, comparing the attitudes of different students who started the program in different years. They are similar to the findings of the SPIBA components and TPB and suggest an increase in students' attitudes over the years, especially for students in the $8^{\text {th }}$ grade. For example, $8^{\text {th }}$ grade students' perception of their general learning skills increased from mean 2.77 (SD 0.65) in 2011 to mean 3.07 (SD $0.54)$ in $2013\left(\mathrm{t}_{(223.294)}=-3.90 \mathrm{p}<0.01\right)$.

Table 20: SPIBA General attitudes towards learning, different students in $7^{\text {th }}$ grade 2011, 2013

\begin{tabular}{lcccccc}
\hline & \multicolumn{5}{c}{$7^{\text {th }}$ grade } \\
\hline & \multicolumn{2}{c}{2011} & \multicolumn{2}{c}{2013} & \\
\cline { 2 - 5 } & \multicolumn{2}{c}{$(\mathrm{N}=115)$} & \multicolumn{2}{c}{$(\mathrm{N}=55)$} & \\
\cline { 2 - 5 } General learning skills & $M$ & $S D$ & $M$ & $S D$ & t-value \\
Self-efficacy & 3.04 & .50 & 3.14 & .53 & -1.20 \\
Evaluation of the learning process & 2.83 & .57 & 3.01 & .52 & -1.88 \\
\hline
\end{tabular}

Table 21: SPIBA General attitudes towards learning, different students in $8^{\text {th }}$ grade 2011, 2013

\begin{tabular}{lcccccc}
\hline & \multicolumn{5}{c}{$8^{\text {th }}$ grade } \\
\hline & \multicolumn{2}{c}{2011} & \multicolumn{2}{c}{2013} & \\
& \multicolumn{2}{c}{$(\mathrm{N}=116)$} & \multicolumn{2}{c}{$(\mathrm{N}=142)$} & \\
\cline { 2 - 6 } & $M$ & $S D$ & $M$ & $S D$ & t-value \\
General learning skills & 2.77 & .65 & 3.07 & .54 & $-3.90^{* *}$ \\
Self-efficacy & 2.69 & .61 & 2.87 & .51 & $-2.68^{* *}$ \\
Evaluation of the learning process & 2.59 & .72 & 2.80 & .58 & $-2.66^{* *}$ \\
\hline$* * \mathrm{p}<0.01 * \mathrm{p}<0.05$ & & & & &
\end{tabular}

Table 22: SPIBA General attitudes towards learning, different students in $9^{\text {th }}$ grade 2011, 2013

\begin{tabular}{lcccccc}
\hline & \multicolumn{5}{c}{$9^{\text {th }}$ grade } \\
\hline & \multicolumn{2}{c}{2011} & \multicolumn{2}{c}{2013} \\
& \multicolumn{2}{c}{$(\mathrm{N}=105)$} & \multicolumn{2}{c}{$(\mathrm{N}=96)$} & \\
\cline { 2 - 5 } General learning skills & $M$ & $S D$ & $M$ & $S D$ & t-value \\
Self-efficacy & 2.99 & .53 & 2.86 & .59 & 1.61 \\
Evaluation of the learning process & 2.66 & .60 & 2.67 & .64 & -0.18 \\
& 2.64 & .64 & 2.69 & .64 & -0.56 \\
\hline
\end{tabular}

In conclusion, our findings vary between the two dimensions that were tested: 'duration of learning' - the effect of learning in the program on the same students; and 'duration of program in school' - the effect of the program on different students in different school years. At the 'duration of learning' dimension students' (same students) motivation and perceptions towards a 1:1 laptop 
program tend to decline over time, between $7^{\text {th }}$ and $9^{\text {th }}$ grade. However, at the 'duration of program in school' dimension we found an increase in students' perceptions towards a 1:1 laptop program over time. In other words, students who participated in the 1:1 program at a later stage (after it started) tended to show more positive attitudes compared to students who participated in earlier years of the 1:1 laptop program in school. These tendencies were found for the SPIBA motivation scales, students' perceptions towards a 1:1 laptop program based on the TPB, and students' general attitudes towards learning.

\section{Discussion}

This study began during the third year of a 1:1 laptop program and was conducted over five years, a period of time that contributed to a longitudinal perspective on the program and allowed us to examine it as part of the school's daily routine, rather than as an innovative initiative (Lei, 2010). The findings indicate an "up \& down" effect, where the attitudes and motivation of students towards learning with a 1:1 laptop change over the years, but this change is not the same when viewed in terms of 'duration of learning' - the effect of learning in the program on the same students; and 'duration of program in school' - the effect of the program on different students in different school years.

At the 'duration of learning' dimension, we found - in the case of both students' cohorts - that students' motivation and attitudes declined as they moved between $7^{\text {th }}$ and $9^{\text {th }}$ grades. This tendency may be related to the decrease in students' enthusiasm over time towards using a 1:1 personal laptop $24 / 7$ as it becomes a routine, but may also be related to the fact that the participants know that the 1:1 program does not continue in high school. A decrease in students' attitudes was reported in the research literature, especially after the first year of a 1:1 program, but recovery was sometimes found between the second and third year (Swallow, 2015). A decline in other aspects of learning with 1:1 laptops, such as student engagement, has also been reported over time (Hur \& Oh, 2012). The results of the SEM analysis emphasize the effect of students' attitudes and self-efficacy on their intention to learn with a 1:1 laptop, so it is crucial to consider what might be done to maintain the students' attitudes towards 1:1 learning and to strengthen self-efficacy and school norms in this context. Otherwise, students' attitudes toward use of their personal laptops may decrease.

However, at the 'duration of program in school' dimension, students' attitudes and motivation increased between 2009-2013. Students in year 2013 displayed more positive attitudes than students from the years before them. The data analysis at the 'duration of program in school' dimension also indicated $8^{\text {th }}$ grade as a significant stage in which students' attitudes and motivation tended to improve over time. Thus, in terms of technology integration, $8^{\text {th }}$ grade is a meaningful time to enhance students' motivation and ICT skills in junior high school. In $9^{\text {th }}$ grade, students may know they are headed to a high school without a 1:1 program and therefore may lose their motivation to study with personal laptops.

These findings may indicate that students who participated in the program in later years were better prepared in terms of their expectations from the program and from 1:1 learning. Spanos and Sofos (2015) found that in a 1:1 laptop program that operated in an elementary and junior high school, the younger students' attitudes were more positive, an aspect that may indicate that students are better prepared for 1:1 learning over time. Another explanation for these findings lies in the fact that in the first years of the laptop implementation, students and teachers need to adapt to a new way of teaching and learning and dedicate time to learning new skills. Over time their skills and the laptop integration improved (Kopcha, 2012; Zheng et al., 2016). The influence of time was also found on students' achievements, which showed a positive effect only after the second year of implementation (Grimes \& Warschauer, 2008). Hence, an explanation for the findings of this study may be that students who started junior high school when the 1:1 program was 
established had better computer skills and learned with more experienced teachers who had already adapted to this new way of teaching and learning. This may be one of the reasons their attitudes are higher than the students who participated in the earlier years of the program and experienced the difficulties of the program's establishment.

This explanation is supported by findings from a long-term research that was conducted on a 1:1 laptop program in the US and found that the use of technology is constantly changing, according to various elements of the school system: technology users, school resources, and the relationships between these systems. In the second year, the program implementation changed to deal with issues that were not predictable at first (Lei, 2010). Therefore, technology integration in schools needs to be continuously adjusted, over time, according to the needs of the school, the increased skills of teachers and students, and new technological developments.

\section{Conclusions}

Due to the high and extensive costs of 1:1 programs, teachers, parents, and policymakers are waiting to see proof of their contribution before investing in additional programs. Further understanding the impact of 1:1 laptops on students and their learning will support the development of future programs (Fleischer, 2012; Zheng et al., 2014). Therefore, in this study we aimed to find out students' attitudes, perceived school norms, self-efficacy, and intention to learn with a 1:1 laptop, in terms of the Theory of Planned Behavior. We also wished to find out whether students' attitudes and perceptions towards learning with a 1:1 laptop are stable, or whether they change over time.

Regarding the first research question, our findings reveal that the Theory of Planned Behavior is feasible in this setting of a 1:1 laptop program. In accordance with the theory, students' attitudes, perceived school norms and self-efficacy significantly contributed to their intention to learn with a 1:1 laptop. Their self-efficacy and intention also significantly contributed to their behavior in terms of learning with a 1:1 Laptop.

Regarding the second research question, we found that attitudes and motivation of students towards learning with a 1:1 laptop changed over the years - what we called an "up \& down effect". Students' attitudes, perceived school norms, self-efficacy, and intention to learn with a laptop tended to decline between the beginning and end of junior high school. However, the same measures (students' attitudes, perceived school norms, self-efficacy, and intention to learn with a laptop) tended to increase the longer the duration of the 1:1 program in school. Therefore, the duration of the 1:1 program in school can positively affect the attitudes and perceptions of students over time.

The findings revealed in this study can assist the implementation of similar programs. The findings emphasize the importance of longitudinal maintenance of students' self-efficacy and attitudes towards learning in 1:1 laptop settings, as these can affect students' intentions to use laptops in the future, and may affect the programs' sustainability. The study also highlights that students' attitudes towards 1:1 learning may change at different ages. In this study, $8^{\text {th }}$ grade was found to be an important time to enhance students' motivation and ICT skills.

Future research can follow 1:1 programs over time in order to detect if the "up \& down" effect identified in this study occurs in other programs, in different schools, and in various contexts. Differences in culture, gender, age, socio-economic status, and other student characteristics can have a significant impact on attitudes and achievements in 1:1 laptop programs. Furthermore, teachers' attitudes are another important aspect that may impact students' technology acceptance. Teachers' attitudes in the 1:1 program presented here were explored by Doron and Spektor-Levy (2015). Future research could investigate teachers' attitudes in light of the "up \& down" effect. These may be investigated through qualitative methodologies. 
Our study has limitations: the small number of students that participated in 2009; the factor 'subjective norms: school norms towards 1:1 learning' is composed from one item, therefore reliability was not calculated. These limitations should be dealt with in future studies. However, the findings of this longitudinal study do show the trends in students' perceptions about learning in a 1:1 laptop model and emphasize the complex impact of these programs on their students, which may vary between different measurements and dimensions: the duration of learning in the program and the duration of the program in school.

\section{References}

Ajzen, I. (1985). From intentions to actions: A theory of planned behavior. In J. Kuhl \& J. Beckman (Eds.), Action-control: From cognition to behavior (pp. 11-39). Heidelberg, Germany: Springer.

Ajzen, I. (1991). The theory of planned behavior. Organizational Behavior and Human Decision Processes, 50(2), 179-211. doi: 10.1016/0749-5978(91)90020-T

American Library Association. (2000). Information literacy competency standards for higher education. Retrieved February 15, 2015, from http://www.ala.org/acrl/sites/ala.org.acrl/files/content/standards/standards.pdf

Balanskat, A., Bannister, D., Hertz, B., Sigillò, E., \& Vuorikari, R. (2013). Overview and analysis of 1:1 learning initiatives in Europe. Institute for Prospective and Technological Studies, Joint Research Centre. Retrieved February 15, 2015 from http://ftp.jrc.es/EURdoc/JRC81903.pdf

Bebell, D., \& Kay, R. (2009). Summary of research findings from the Berkshire 1:1 Laptop Program. Paper presented at the Annual Meeting of the National Educational Computing Conference. Retrieved June 1, 2016 from http://www.bc.edu/research/intasc/PDF/BWLI_Year3Report.pdf

Bennett, S., \& Maton, K. (2010). Beyond the 'digital natives' debate: Towards a more nuanced understanding of students' technology experiences. Journal of Computer Assisted Learning, 26(5), 321-331. doi: 10.1111/j.1365-2729.2010.00360.x

Blackley, S., \& Walker, R. (2015). One-to-one laptop programs: Is transformation occurring in mathematics teaching. Issues in Educational Research, 25(2), 99-117.

Blau, I., \& Peled, Y. (2012). Teachers' openness to change and attitudes towards ICT: Comparison of laptop per teacher and laptop per student programs. Interdisciplinary Journal of e-Learning and Learning Objects, 8, 73-82. Retrieved June 1, 2016 from http://www.ijello.org/Volume8/IJELLOv8p073082Blau0800.pdf

Cavanaugh, C., Dawson, K., \& Ritzhaupt, A. (2012). An evaluation of the conditions, processes, and consequences of laptop computing in K-12 classrooms. Journal of Educational Computing Research, 45(3), 359-378. doi: 10.2190/EC.45.3.f

Cheon, J., Lee, S., Crooks, S. M., \& Song, J. (2012). An investigation of mobile learning readiness in higher education based on the theory of planned behavior. Computers \& Education, 59(3), 1054-1064. doi: 10.1016/j.compedu.2012.04.015

Courtois, C., Montrieux, H., De Grove, F., Raes, A., De Marez, L., \& Schellens, T. (2014). Student acceptance of tablet devices in secondary education: A three-wave longitudinal cross-lagged case study. Computers in Human Behavior, 35, 278-286. doi: 10.1016/j.chb.2014.03.017

Crook, S. J., Sharma, M. D., Wilson, R., \& Muller, D. A. (2013). Seeing eye-to-eye on ICT: Science student and teacher perceptions of laptop use across 14 Australian schools. Australasian Journal of Educational Technology, 29(1), 82-95. doi: 10.1080/09500693.2014.982229

Davis, F. D. (1989). Perceived usefulness, perceived ease of use, and user acceptance of information technology. MIS Quarterly, 13(3), 319-340. 
Doron, E., \& Spektor-Levy, O. (2015). The evolvement of teachers' role and professional identity in 1:1 personal laptop classrooms. Paper presented at the EARLI - 16th Biennial Conference, Limassol, Cyprus.

Dunleavy, M., Dexter, S., \& Heinecke, W.F. (2007). What added value does a 1:1 student to laptop ratio bring to technology-supported teaching and learning? Journal of Computer Assisted Learning, 23, 440-452. doi: 10.1111/j.1365-2729.2007.00227.x

Fleischer, H. (2012). What is our current understanding of one-to-one computer projects: A systematic narrative research review. Educational Research Review, 7(2), 107-122. doi:10.1016/j.edurev.2011.11.004

Fraillon, J., Ainley, J., Schulz, W., Friedman, T., \& Gebhardt, E. (2014). Preparing for life in a digital age. The IEA international computer and information literacy study international report. Champagne, IL: Springer. doi: 10.1007/978-3-319-14222-7

Grant, B. M. M., \& Carolina, S. (2015). Teaching and learning with mobile computing devices: Case study in K-12 Classrooms. TechTrends, 59(4). doi: 10.1007/s11528-015-0869-3

Grimes, D., \& Warschauer, M. (2008). Learning with laptops: A multi-method case study. Journal of Educational Computing Research, 38(3), 305-332. doi: 10.2190/EC.38.3.d

Harper, B., \& Milman, N. B. (2016). One-to-one technology in K-12 classrooms: A review of the literature from 2004 through 2014. Journal of Research on Technology in Education, 48(2), 129-142. doi: org/10.1080/15391523.2016.1146564

Holcomb, L. (2009). Results and lessons learned from 1:1 laptop initiatives: A collective review. TechTrends, 53(6), 49-55. doi: 10.1007/s11528-009-0343-1

Hooft, M., Swan, K., Cook, D., \& Lin, Y. (2007). What is ubiquitous computing? In M. Hooft \& K. Swan (Eds.), Ubiquitous computing in education: Visible technology invisible outcomes (pp. 3-19). Lawrence Erlbaum Associates.

Hu, L. T., \& Bentler, P. M. (1999). Cutoff criteria for fit indexes in covariance structure analysis: Conventional criteria versus new alternatives. Structural Equation Modeling: A Multidisciplinary Journal, 6(1), 1-55. doi: 10.1080/10705519909540118

Hu, W. (2007, May 4). Seeing no progress, some schools drop laptops. The New York Times. Retrieved February, 152015 from http://www.nytimes.com/2007/05/04/education/04laptop.html?pagewanted=all\& $\mathrm{r}=0$

Hur, J. W., \& Oh, J. (2012). Learning, engagement, and technology: Middle school students' three-year experience in pervasive technology environments in South Korea. Journal of Educational Computing Research, 46, 295-312. doi:10.2190/EC.46.3.e

Islam, M. S., \& Grönlund, Å. (2016). An international literature review of 1: 1 computing in schools. Journal of Educational Change, 17(2), 191-222. doi: 10.1007/s10833-016-9271-y

Kay, K. (2010). 21st century skills: Why they matter, what they are, and how we get there. In J. Bellanca, \& R. Brandt (Eds.), 21st century skills: Rethinking how students learn. Bloomington, IN: Soloution Tree.

Kline, R. B. (2011). Principles and practice of structural equation modeling. New York: Guilford publications.

Kopcha, T. J. (2012). Teachers' perceptions of the barriers to technology integration and practices with technology under situated professional development. Computers \& Education, 59(4), 1109-1121. doi: 10.1016/j.compedu.2012.05.014

Léger, M. T., \& Freiman, V. (2016). A narrative approach to understanding the development and retention of digital skills over time in former middle school students, a decade after having used one-to-one laptop computers. Journal of Research on Technology in Education, 48(1), 57-66.

doi: $10.1080 / 15391523.2015 .1103150$ 
Lei, J. (2010). Conditions for ubiquitous computing: What can be learned from a longitudinal study. Computers in the Schools, 27(1), 35-53.doi:10.1080/07380560903536264

Lowther, D. L., Inan, F. A., Ross, S. M., \& Strahl, J. D. (2012). Do one-to-one initiatives bridge the way to 21 st Century knowledge and skills? Journal of Educational Computing Research, 46(1), 1-30. doi: 10.2190/EC.46.1.a

Lowther, D. L., Ross, S., \& Morrison, G. (2003). When each one has one: The influences on teaching strategies and student achievement of using laptops in the classroom. Educational Technology, Research and Development, 51(3), 23-44. doi: 10.1007/BF02504551

Menashe, K. (2008). Learning with laptops and virtual campus as a routine: Development of learning capabilities, information literacy and affective aspects among 6th and 7th grade school students. (Unpublished master's thesis).School of Education, Bar Ilan University, Israel. [In Hebrew]

Mouza, C. (2008). Learning with laptops: Implementation and outcomes in an urban, under-privileged school. Journal of Research on Technology in Education. 40(4), 447-472. doi: 10.1080/15391523.2008.10782516

Nachmias, R., Mioduser, D., \& Forkosh Baruch, A. (2009). SITES 2006 ICT in mathematics and science education study in Israel. Ramot, Tel-Aviv. [In Hebrew].

Penuel, W. R. (2006). Implementation and effects of one-to-one computing initiatives: A research synthesis. Journal of Research on Technology in Education, 38(3), 329-348. doi: 10.1080/15391523.2006.10782463

Perlman, B. (2010). Designing new learning environments to support 21st century skills. In J. Bellanca \& R. Brandt (Eds.), 21st Century Skills: Rethinking how students learn. Bloomington, IN: Solution Tree.

Pintrich, P.R., Smith, D.A.F., Garcia, T., \& McKeachie, W.J. (1993). Reliability and predictive validity of the motivated strategies for learning questionnaire (MSLQ). Educational and Psychological Measurement, 53, 801-813. doi: 10.1177/0013164493053003024

Resnick, M. (2002). Rethinking learning in the digital age. In G. Kirkman (Ed.), The global information technology report: Readiness for the networked word. Oxford, UK: Oxford University Press.

Reynolds, D., Treharne, D., \& Tripp, H. (2003). ICT-The hopes and the reality. British Journal of Educational Technology, 34(2), 151-167. doi: 10.1111/1467-8535.00317

Rosen, Y., \& Beck-hill, D. (2012). Intertwining digital content and a one-to-one laptop environment in teaching and learning: Lessons from the time to know program. Journal of Research on Technology in Education, 44(3), 225-241. doi: 10.1080/15391523.2012.10782588

Spanos, D., \& Sofos, A. (2015). The views and attitudes of students participating in a one-to-one laptop initiative in Greece. Education and Information Technologies, 1-17. doi:10.1007/s10639-013-9299-z

Spektor-Levy, O., \& Granot-Gilat, Y. (2012). The impact of learning with laptops in 1:1 classes on the development of learning skills and information literacy among middle school students. Interdisciplinary Journal of E-Learning and Learning Objects, 8, 83-96. Retrieved from https://www.informingscience.org/Publications/1729

Spektor-Levy, O., Menashe, K., Berger-Tikochinski, T., \& Doron, E. (2011). The feasibility of ubiquitous computing in school. Longitudinal Study in 1:1 classes suggests-time matters. Paper presented at the $3 r d$ International Conference on Computer Supported Education, Noordwijkerhout, Netherlands. Retrieved February 15, 2015, from http://www.csedu.org/Abstracts/2011/UeL_2011_Abstracts.htm .

State Comptroller. (2011). 62nd Annual report. Retrieved May 30, 2015 from http://www.mevaker.gov.il/he/Reports/Report_117/a98fb0e6-1f5a-4c6c-8d21-3e2a4953290b/7553.pdf [In Hebrew]

Swallow, M. (2015). The year-two decline: Exploring the incremental experiences of a 1:1 technology initiative. Journal of Research on Technology in Education, 47(2), 122-137. doi: 10.1080/15391523.2015.999641 
Teo, T. (2015). Comparing pre-service and in-service teachers' acceptance of technology: Assessment of measurement invariance and latent mean differences. Computers \& Education, 83, 22-31. doi:10.1016/j.compedu.2014.11.015

Valtonen, T., Kukkonen, J., Kontkanen, S., Sormunen, K., Dillon, P., \& Sointu, E. (2015). The impact of authentic learning experiences with ICT on pre-service teachers' intentions to use ICT for teaching and learning. Computers \& Education, 81, 49-58. doi:10.1016/j.compedu.2014.09.008

Venkatesh, V., Morris, M. G., Davis, G. B., \& Davis, F. D. (2003). User acceptance of information technology: Toward a unified view. MIS Quarterly, 27(3), 425-478.

Warschauer, M. (2007). Information literacy in the laptop classroom. Teachers College Record, 109, 25112540.

Warschauer, M. (2008). Laptops and literacy: A multi-site case study. Pedagogies, 3, 52-67. doi: $10.1080 / 15544800701771614$

Zheng, B., Arada, K., Niiya, M., \& Warschauer, M. (2014). One-to-one laptops in K-12 classrooms: Voices of students. Pedagogies: An International Journal, 9(4), 279-299. doi: 10.1080/1554480X.2014.955499

Zheng, B., Warschauer, M., Lin, C. H., \& Chang, C. (2016). Learning in one-to-one laptop environments: A meta-analysis and research synthesis. Review of Educational Research. doi: $10.3102 / 0034654316628645$

\section{Biographies}

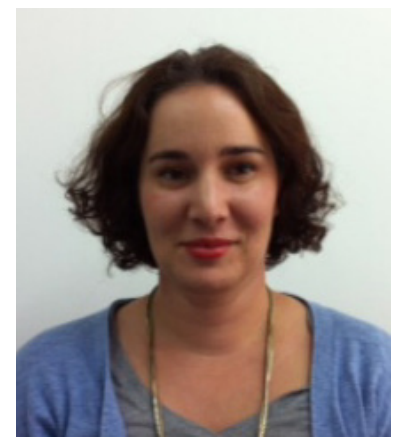

Tal Berger-Tikochinski is a $\mathrm{PhD}$ candidate at the School of Education at Bar-Ilan University. She holds a B.A degree in Behavioral Sciences from Ben-Gurion University and an M.A degree in Sociology of Education from the Hebrew University of Jerusalem, Israel. Mrs. BergerTikochinski is a researcher at the Henrietta Szold Institute - The National Institute for Research in the Behavioral Sciences in Israel.

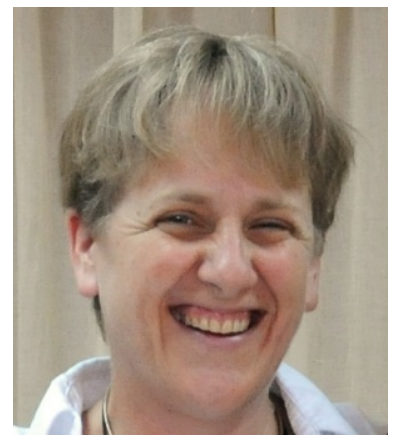

Prof. Michal Zion, PhD, from The Hebrew University, Jerusalem, Israel, in Molecular Biology (Cancer Research). Prof Zion is a Vice Director, School of Education; Head of the Science Education Program and the Biology Teaching Program, the School of Education, Bar-Ilan University, Ramat-Gan, Israel. She is the Academic Head of The National Center for Support and Development of Biology School Laboratories. Her main research interests include inquiry-based learning and teaching; Developing scientific environmental and health literacy; Metacognition; Homeostasis - a fundamental principle in biology education; Computer-based learning environments. 


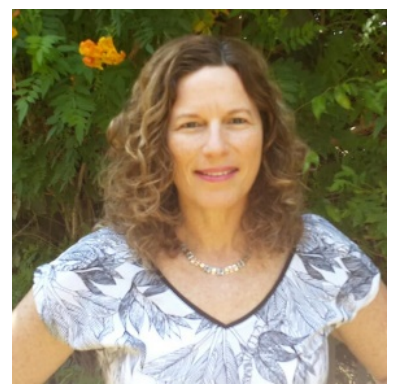

Dr. Ornit Spektor-Levy is a faculty member at the Science Education Center, School of Education, Bar Ilan University. PhD from the Weizmann Institute for Science. Her educational research focuses on Scientific communication, ICT in education, information literacy, development of scientif99ic curiosity and literacy, professional development of science teachers. She is the director of the Israeli National teacher center for STEM in preschool. 